Discussion

Papers

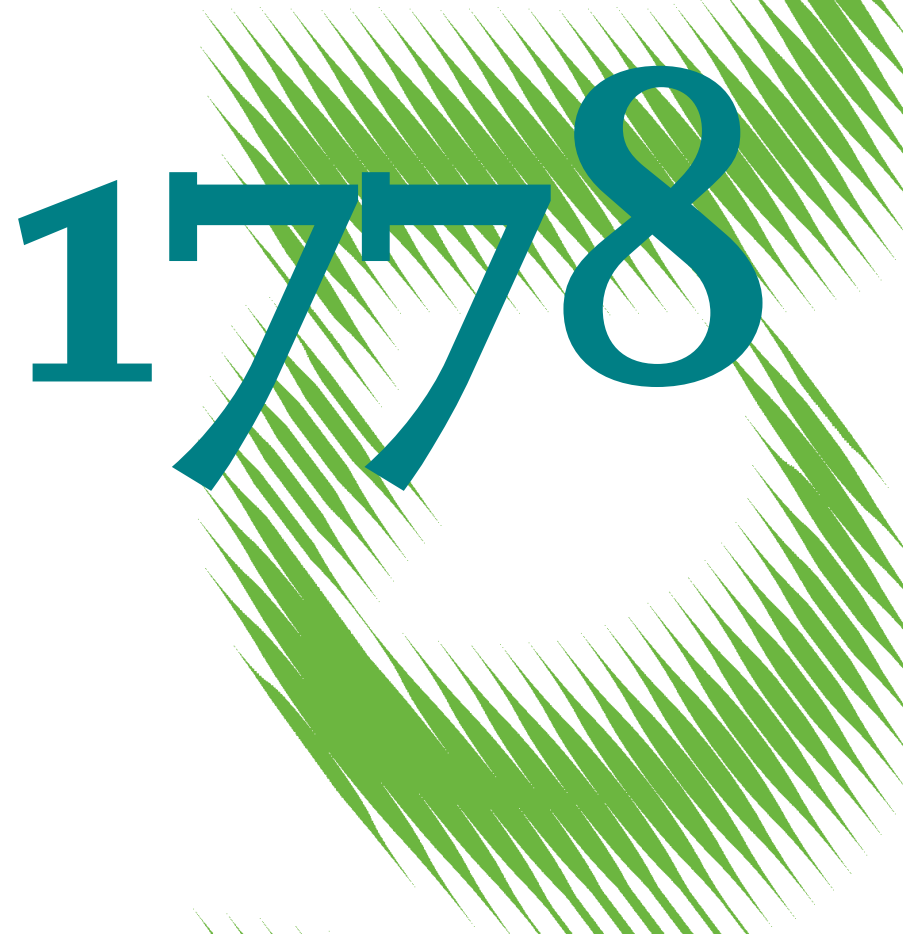

Social Policy or Crowding-Out? Tenenat Protection in Comparative Long-Run Perspective 
Opinions expressed in this paper are those of the author(s) and do not necessarily reflect views of the institute.

IMPRESSUM

(C) DIW Berlin, 2019

DIW Berlin

German Institute for Economic Research

Mohrenstr. 58

10117 Berlin

Tel. +49 (30) $89789-0$

Fax +49 (30) $89789-200$

http://www.diw.de

ISSN electronic edition 1619-4535

Papers can be downloaded free of charge from the DIW Berlin website:

http://www.diw.de/discussionpapers

Discussion Papers of DIW Berlin are indexed in RePEc and SSRN:

http://ideas.repec.org/s/diw/diwwpp.html

http://www.ssrn.com/link/DIW-Berlin-German-Inst-Econ-Res.html 


\title{
Social policy or crowding-out? \\ Tenant protection in comparative long-run perspective
}

\author{
Konstantin A. Kholodilin ${ }^{\mathrm{a}, \mathrm{b}}$, Sebastian Kohl ${ }^{\mathrm{c}, \mathrm{d}}$, Yulia Prozorova ${ }^{\mathrm{b}}$, Julien Licheron ${ }^{\mathrm{e}}$ \\ ${ }^{a}$ DIW Berlin, Mohrenstraße 58, 10117, Berlin, Germany \\ ${ }^{b}$ NRU HSE, Kantemirovskaya ul., 3, korp. 1, 194100, St. Petersburg, Russia \\ ${ }^{c}$ Max-Planck-Institut für Gesellschaftsforschung Paulstraße 3, 50676, Cologne, Germany \\ ${ }^{d}$ Uppsala University, Sociology and IBF, Sweden \\ ${ }^{e}$ LISER, 11 Porte des Sciences, 4366 Esch-sur-Alzette, Luxembourg
}

\begin{abstract}
In the shadow of homeownership and public housing, social policy through the regulation of private rental markets is a neglected and underestimated field of social policy. This paper, therefore, presents unique new data on the development of private tenancy legislation through the binary coding of rent control, the protection of tenants from eviction, and rental housing rationing laws across more than 25 countries and 100 years. This long-run perspective reveals the dynamic effects of rent control on the rise of homeownership as the dominant tenure during the 20th century. We find that both rent regulation and rationing legislation effectively increased homeownership, but only up to a certain threshold. We suggest that the short-term lure of an inexpensive social policy for tenants has led to the long-term marginalization of rental markets in many countries.
\end{abstract}

Keywords: Homeownership, rent control, tenure security, housing rationing, dynamic panel data model.

JEL codes: C23, O18, R38.

\footnotetext{
${ }^{\text {«T }}$ We thank Espen Andersen, Philip Ando, Andrés Blanco Blanco, Emily Dix, Christian Enzer, Christoph Enzler, Markus Forster, Rosemary Goodyear, Hildur Gróa Gunnarsdóttir, Kari Gyllander, Alejandro Jacobo Ostapchuk, Jakob Juul-Sandberg, Annika Klintefelt, Julija Kolomijceva, Irene Kull, Jussi Lahtinen, Mette Lindbjerg Jørgensen, Antii Malinen, Valentinas Mikelénas, Dimitrios Moschos, Peter Nägele, Mounira Nouri, Kua Hui Shan, Dmitriy Shevyakov, Boriss Siliverstovs, Jón Rúnar Sveinsson, Irina Veinberga, and Rima Zenevskien? for their kind help in finding the statistical data and legal acts. The authors confirm that the paper involves no interest conflicts.
} 


\section{Contents}

1 Introduction $\quad 1$

2 Literature on rent regulation and homeownership determinants 4

3 Data: tenancy regulation in the long-run $\quad 5$

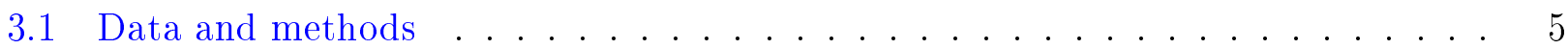

3.2 Tenancy regulation: a descriptive account $\ldots \ldots \ldots . \ldots$

4 Estimation results $\quad 11$

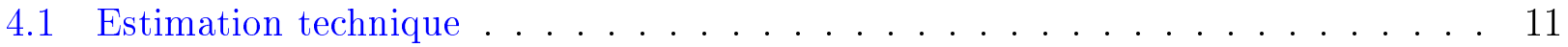

4.2 Diagnostic tests . . . . . . . . . . . . . . . . . 13

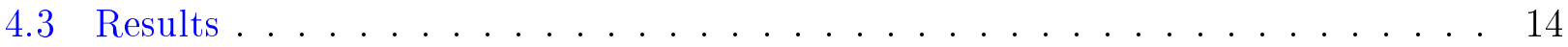

$\begin{array}{llr}5 & \text { Discussion and conclusion } & 16\end{array}$

$\begin{array}{ll}\text { Literature } & 17\end{array}$

$\begin{array}{ll}\text { Appendix } & 21\end{array}$ 


\section{List of Tables}

1 Estimation results of panel data model: basic specification . . . . . . . . 15

A1 List of countries, for which regulation indices are constructed . . . . . . . . 21

A2 Literature on measurement of housing regulations . . . . . . . . . . . . 22

A3 Literature on HOR determinants . . . . . . . . . . . . . . . 23

A3 Literature on HOR determinants . . . . . . . . . . . . . . 24

A4 Description of variables used in the analysis ............... 25

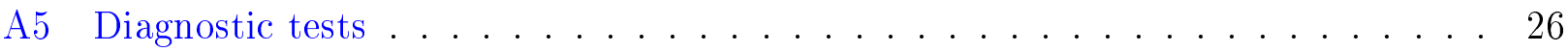

\section{List of Figures}

1 Evolution of homeownership rate in the world, 1900-2010s . . . . . . . . 2

2 Rental regulation intensity by continents . . . . . . . . . . . . . 10

3 Rental regulation intensity in Europe by legal origin . . . . . . . . . . . . . 12 


\section{Introduction}

A significant number of citizens, especially in urban areas depend on private rental markets for housing provision. In German-speaking countries, this makes up a majority of households and the private tenancy rate is increasing in many high-homeownership countries in the aftermath of the Great Recession. Historically, private tenancy has dominated large parts of the 20th century: interpolated homeownership rates crossed the 50 percent threshold as early as 1955 in Spain, in 1968 in Portugal, in 1970 in Great Britain, 1982 in France, and 1998 in the Netherlands. Even if the remainder is partially public or municipal housing, private tenancy is not negligible as public housing has been declining in most countries since the 1970s (Kohl, 2017). In general, from the end of World War II and until the Great Recession of 2008-2009, homeownership rates increased. In the 2010s, they stabilized and even appear to be declining; see Figure 1.

Despite its prominence, both historically and at present, the private rental market, as a field of social policy, is neglected in both the academic literature and the political realm when compared to the other two housing market segments: the owner-occupier and the public housing sectors. For instance, in an analysis of party manifestos since 1945 across 19 countries, the issue of rent regulation appears significantly less frequently than questions of homeownership and public housing (Kohl, 2018a). In economics, the central question of whether rent regulation has negative effects on supply is addressed by very sketchy evidence so far. This low salience is probably due to the fact that the other two sectors have much more budgetary importance. A reason for the limited academic attention lies in the lack of comparative data on very specific national regulatory environments. Whereas public and owner-occupier housing is much more a question of finance and budgets, private renting is more one of legal regulation.

This paper presents new content-coded data on legislation in the three dominant domains of the regulation of private tenancy - rent control, security of tenure, and housing rationing - covering a panel of 58 countries from the First World War through 2017, see Table A1 in Appendix. The descriptive analysis confirms that tenancy legislation was pushed forward by the two World Wars, especially in Europe, where a first generation of rent-freezing regulation was passed, tenure security implemented, and short-term rationing measures were used. The second generation of more flexible rent controls replaced the rent-freezes in the post-war years 
Figure 1: Evolution of homeownership rate in the world, 1900-2010s

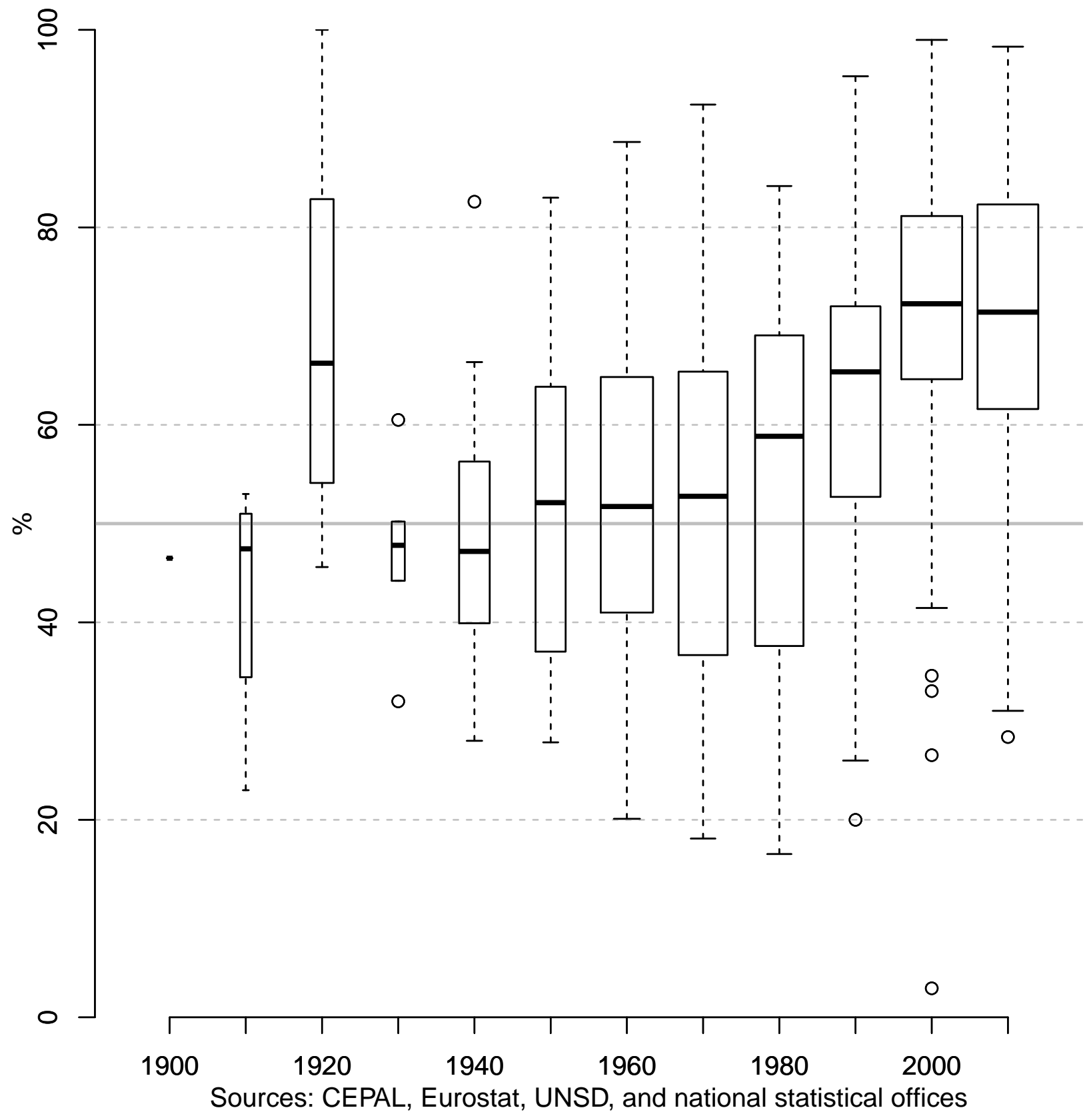


nearly everywhere outside developing countries and the rationing was mostly phased out, while levels of tenure security, once achieved, were hardly ever retrenched. Europe scores generally higher in terms of tenure security and second-generation rent controls than all other continents, particularly in comparison to Anglo-Saxon countries.

The paper further investigates the question of whether rent legislation is an indirect factor behind the rise of homeownership in all countries through the 20th century. Economists' stock assumption is that rent legislation of any kind makes investment in rental real estate less attractive and incites landlords to sell existing rental units and to not construct new ones. Our multivariate panel data models produce confirmatory findings: both rationing and rent regulation, but not tenure security regulation, have positive effects on homeownership rates. Interestingly, the association between rent legislation and homeownership is non-linear (negative quadratic term): additional rent legislation beyond a certain threshold weakens the effect on homeownership again. Our interpretation is that tenancy legislation, rent regulation in particular, is used as an inexpensive social policy favoring tenant majorities at the expense of landlord minorities and thereby reducing the very same form of tenure it is meant to protect. While many subsidies have been spent on pulling more households into homeownership, too restrictively regulating private tenancy has worked as a push away from tenancy and into homeownership. From a cross-country perspective, this helps explain why tenancy-regulated Europe caught up with the historically high homeownership rates of tenancy-underregulated Anglo-Saxon countries. It also explains why European homeownership rates are still below those of the tenancy-overregulated Global South.

The paper is organized as follows: after reviewing the literature on rent regulation and its effects on homeownership, we present the data, methods, and descriptives of the new rent regulation indices. We then report and discuss the multivariate results of the regressions on homeownership rates. The discussion draws some parallels between rent legislation and other welfare policies, suggesting that much of the homeownership development and variation can be explained from the rental side of the market. 


\section{Literature on rent regulation and homeownership determinants}

In this section, we first review the rather patchy literature on rent regulation in general. We then focus on the rent-regulation effects on homeownership in particular and on studies explaining homeownership as they inform our multivariate analysis.

There is already a small but growing body of literature on the measurement of housing market regulations; see Table A2 in Appendix for an overview. The majority of studies assess the stringency of housing policies for a single period of time. The cross-sectional dimension varies between four (Miletić, 2016) and 126 countries (Global Property Guide). The degree of regulation is measured for various points of time: the stringency of rent control by Malpezzi and Ball (1993) for 1991, a procedural formalism index by Djankov et al. (2003) for 2000, a rent control index by Andrews et al. (2011) for 2009, as well as landlord and tenant law and practice of the Global Property Guide for 2017. Kholodilin (2017) is the first study, which indexes the evolution of governmental regulations over time, while Weber (2017) is the first researcher to develop a panel of indices encompassing 18 countries between 1973 and 2016.

There are a number of studies looking at the different effects of rent regulation, such as on rents and mobility (Munch and Svarer, 2002; Krol and Svorny, 2005); maintenance quality (Kutty, 1996); the efficiency of allocation and segregation (Glaeser, 2003), (Field et al., 2008); and homelessness (Grimes and Chressanthis, 1997; Early and Olsen, 1998). There are fewer studies of the effects of tenure-security regulation, one exception being Iwata (2002)'s study on housing supply. Other than the bivariate analyses of (Blanco Blanco, 2014), studies do not use multivariate methods to evaluate the effects of tenancy regulation on the large competing market segment, namely homeownership.

By contrast, the rise of homeownership in almost all countries during the last century has received much more attention; see Kohl (2017). There are many micro-level studies of tenure choice for homeownership (Borjas, 2002; Burgess, 1982; Tan, 2008); however, more relevant for the present context, there are also macro-level studies explaining homeownership rates across cities, regions, or countries. Table A3 in Appendix lists detailed findings about the determinants of homeownership rates.

Summing up, all these studies include variables concerning the social characteristics of the population (age structure, level of education, urbanization, percentage of divorced and married 
people, presence of children in the family), indicators of economic development (median income, GDP per capita, growth index), as well as financial and tax regulation indicators (reform indices, tax rates). In most cases, these factors are shown to be significant. In addition, some take into account other factors including geographical characteristics, ideological orientation, political party, political aspects, square-meter prices and their changes. However, not all are significant. These studies have a strong US bias, are cross-sectional or lack dynamic specifications, and are based on post-1980 data, i.e., a time when arguably most homeownership increases had already taken place. Due to the lack of tenancy-regulation data, its effect has not yet been properly examined.

\section{Data: tenancy regulation in the long-run}

\subsection{Data and methods}

In order to assess the impact of governmental regulations, they must be measured. There are two major concerns regarding the measurement of legislation. First, law enforcement may differ across the sample and there is complexity in enforcement-quality measurement. Second, formally different legal systems may lead to the same functional outcome, the only difference is in the means. However, these arguments cannot be applied to the case examined in our research for two reasons. First, rental market law is statutory and deviations from statutes rarely occur. Second, with some key variables, we measure functional differences, not pure formalism.

The common approach to measuring formal regulations in the literature is constructing indices. However, some authors underline the complexity of measuring formal regulations and raise some methodological objections; see Deakin et al. (2007). One of the most important problems is the weighting issue; for instance, when equal weights are used in the index for all the countries. Another problem is the inability of binary variables to capture gradations in the effects of legal rules in different countries. Deakin et al. (2007) stress that these problems are inevitable for any coding project, so the aim is to approximate reality as closely as possible. Different papers propose various methods for index construction. The general idea most commonly used is that higher index values refer to a higher degree of control, or, in other words, stricter legal protection; see Deakin et al. (2007), Botero et al. (2004), LaPorta et al. (1998). 
In our approach, which is an extended version of the methodology of Weber (2017), legal acts are quantified in several steps. The first step consists of exploring the literature summarizing housing market regulations in the countries of interest. In a few select cases, there is already a systematic description of the evolution of such legislation. The main sources of such information are the Tenlaw project at the Universität Bremen ${ }^{1}$ for the $28 \mathrm{EU}$ member states plus Japan, Norway, Serbia, Switzerland, and Turkey; the "Tenancy Law and Procedure in the EU" project of the European University Institute in Florence ${ }^{2}$ for 13 EU member states plus Switzerland; International Labour Office (1924) for the origins of housing policies in 17 European countries (Austria, Belgium, Czechoslovakia, Denmark, Finland, France, Germany, Great Britain, Hungary, Italy, Netherlands, Norway, Poland, Russia, Sweden, Switzerland, and Yugoslavia); historical and legal studies; as well as the preambles to legal acts or parliamentary discussions of draft laws providing justifications for the regulations (e.g., Belgium, Portugal, and Romania).

At the second step, a list of the relevant legal acts is compiled and a search for their original (not revised) texts is conducted. Since we are interested in the evolution of housing legislation, we need the "real-time" texts, as formulated at the moment of their enactment. Most frequently, such texts are in government or official gazettes. Fortunately, many of these gazettes are digitized and available as online archives and it is relatively easy to search for the necessary information. In other cases, laws can be obtained free of charge by contacting national parliaments (e.g., as is the case for Denmark, Iceland, and Norway). Still other countries charge fees for providing the relevant laws (e.g., Bulgaria, Singapore, and Sweden). Where we were unable to locate laws as published in an official gazette, we use drafts of the laws from parliamentary proceedings (e.g., Belgium and Switzerland). In the worst case, answers to questions submitted remotely were not forthcoming (some African, Asian, as well as Latin American and Caribbean countries) or one must visit a library in the country of interest.

At the third step, the compiled legal acts are summarized. The relevant provisions are identified and recorded. In particular, the following fields are captured: the area of application, rent

\footnotetext{
${ }^{1}$ http: //www . tenlaw.uni-bremen.de/.

${ }^{2}$ https : //www.eui.eu/DepartmentsAndCentres/Law/ResearchAndTeaching/ResearchThemes/ Project TenancyLaw.
} 
control, tenant protection, housing rationing, and the bodies responsible for conflict resolution and the regulation of the housing sphere. Language barriers are a significant challenge at this stage. In many cases, knowledge of foreign languages permits the co-authors to understand the legal texts, these include English, French, German, Italian, Russian, Spanish, and Swedish; with Russian being the authors' mother tongue. In other cases, native speakers help decipher these texts (e.g., those in Greek and Finnish). Otherwise, the authors use machine translation (e.g., Google Translate) in order to translate the texts. Although the quality of modern machine translations is relatively high, there is still a room for error, especially for older texts.

At the fourth step, textual summaries of legal acts are mapped into numeric values. Here, we rely upon the approach of Weber (2017) to code rent law and tenure security and Kholodilin (2017) to code housing rationing. Based on a set of questions formulated in these two studies, binary variables are constructed that equal one, if regulation is more stringent and zero otherwise:

$$
I_{j t}^{k}= \begin{cases}1, & \text { if restriction } j \text { of type } k \text { is present in period } t \\ 0, & \text { otherwise }\end{cases}
$$

Below, the coding is described in more detail.

Rent control. Weber (2017) defines six binary variables: "Real rent freeze" (the rents are not allowed to grow faster than inflation), "Nominal rent freeze" (the rents are frozen in nominal terms), "Rent level control" (a government body, arbitration council, or court fixes the rent level at the beginning of new contracts), "Intertenancy decontrol" (if rent control ceases with a change of tenant), "Other specific rent decontrol" (certain types of dwellings or settlements are no longer subject to rent control), and "Specific rent recontrol" (certain types of dwellings or settlements are subject to more stringent controls).

Tenure security. Here, four binary variables are used: "Eviction protection during the term or period" and "Eviction protection at the end of the term or period" take the value one, if, in order to evict a tenant during the contract term or at the end of it, the landlord is required to present justified reasons. The "Minimum duration" variable equals one, if the contract duration must be at least two years, while the "Short-term tenancies" variable is 1, if letting dwellings for a period of less than one year is prohibited.

Housing rationing. This policy is approximated with eight binary variables. "Registration 
of housing" equals 1 , if landlords are obliged to report vacant, or all available, premises. The binary variable "Protection of housing" is 1 , if it is prohibited to use dwellings for non-residential purposes, merge or demolish them, or to convert rental dwellings into owner-occupied dwellings. The variable "Creation of housing space" equals 1, if the state prescribes the use of all available space for housing purposes, e.g., through the reconstruction or conversion of non-residential premises or through the subdivision of big dwellings into smaller ones. "Requisition" equals 1 , if requisition with subsequent compulsory letting of vacant dwellings is conducted. "Restriction of freedom to move" is 1 , if residential mobility is restricted: for example, if access to areas with an acute housing shortage is closed to all persons, who are neither "indispensable" for these areas nor residing there on a permanent basis. "Conservation of social composition" is 1 , if a balanced social composition of the population in particular urban areas is protected through the interdiction of upgrading the dwellings to a state considered being above the standard level. The variable "Housing consumption norms" equals 1, if restrictions on the amount of housing that might be used by tenants are imposed. The dummy "Nationalization of housing" takes the value 1 , if the state nationalizes housing stock, and 0 , if no nationalization or privatization occurs. Unlike requisition, nationalization means the loss of property rights for the owner and no compensation for property taken.

For each regulation type, $k$, a composite index is computed as a simple average of binary variables:

$$
I_{t}^{k}=\frac{1}{N_{k}} \sum_{j=1}^{N_{k}} I_{j t}^{k}
$$

where $k=\{$ Rent laws, Tenure security, Housing rationing $\}$.

The binary and composite indices are constructed for a large panel of countries; see Table A1 in Appendix. The choice of countries is dictated by the availability of legal acts. The best coverage exists for Europe and Latin America. In Africa, legislation was coded only for a few former French and Portuguese colonies, since it was relatively easy to locate the historical legal acts for them. For North American countries, coding is complicated by the fact that housing regulations there are created at the regional level, including not only states and provinces, but also cities.

Finally, an even more general index can be constructed (rental market regulation index): 


$$
\mathrm{RMRI}=\frac{I_{t}^{\text {Rent laws }}+I_{t}^{\text {Tenure security }}}{2}
$$

which simultaneously accounts for both rent control and protection from eviction.

\subsection{Tenancy regulation: a descriptive account}

The resulting country-specific indices aggregated at the continent level are presented in Figure 2. National tenancy regulation became a widespread phenomenon in all countries affected by war-time inflation during World War I. Private rental contracts were previously only formally regulated like any other tenancy in most Civil Codes and - disregarding general usury laws - were not subject to any state restrictions. However, with families of active soldiers facing eviction on the home front, states used temporary ordinances to freeze rents, interdict evictions, and even redistribute housing space. This war-time consumer-socialism was usually extended to all tenants and survived the war longer than governments had originally intended; see Führer (1995). The demand of returning soldiers and postponed family formation, along with political radicalism and private-capital shortages, made social policy through tenancy regulation a necessity, even after the war in Europe. Tenancy security became a permanent part of many Civil Codes and rent controls were repeatedly prolonged throughout the 1920s, whereas the emergency measures of direct rationing were usually cut back. While the 1930s was a short era of liberalization, World War II forced countries - this time on a global scale to re-activate strong war-time measures. These emergency measures largely disappeared after World War II, while the first generation of rent controls, in form of rent freezes, gradually gave way to the second generation of softer restrictions (Arnott, 1995).

Comparatively, Europe was the leader of both hard and soft rent control, tenancy security, and rationing measures. Anglo-Saxon countries were much more reluctant to introduce similar measures and faster in abolishing them. Other countries followed the European example, but with a lag and with less intensity. This becomes, perhaps, most visible for the forceful redistribution of housing and tenants, arguably the most intrusive ones; see Figure 2 showing regulation intensity by continent. Only North America appears to have escaped such a largescale policy. It is known, though, that some US cities, e.g., Santa Monica (California) used forms of housing rationing such as the obligatory registration of vacant housing and the prohi- 
Figure 2: Rental regulation intensity by continents

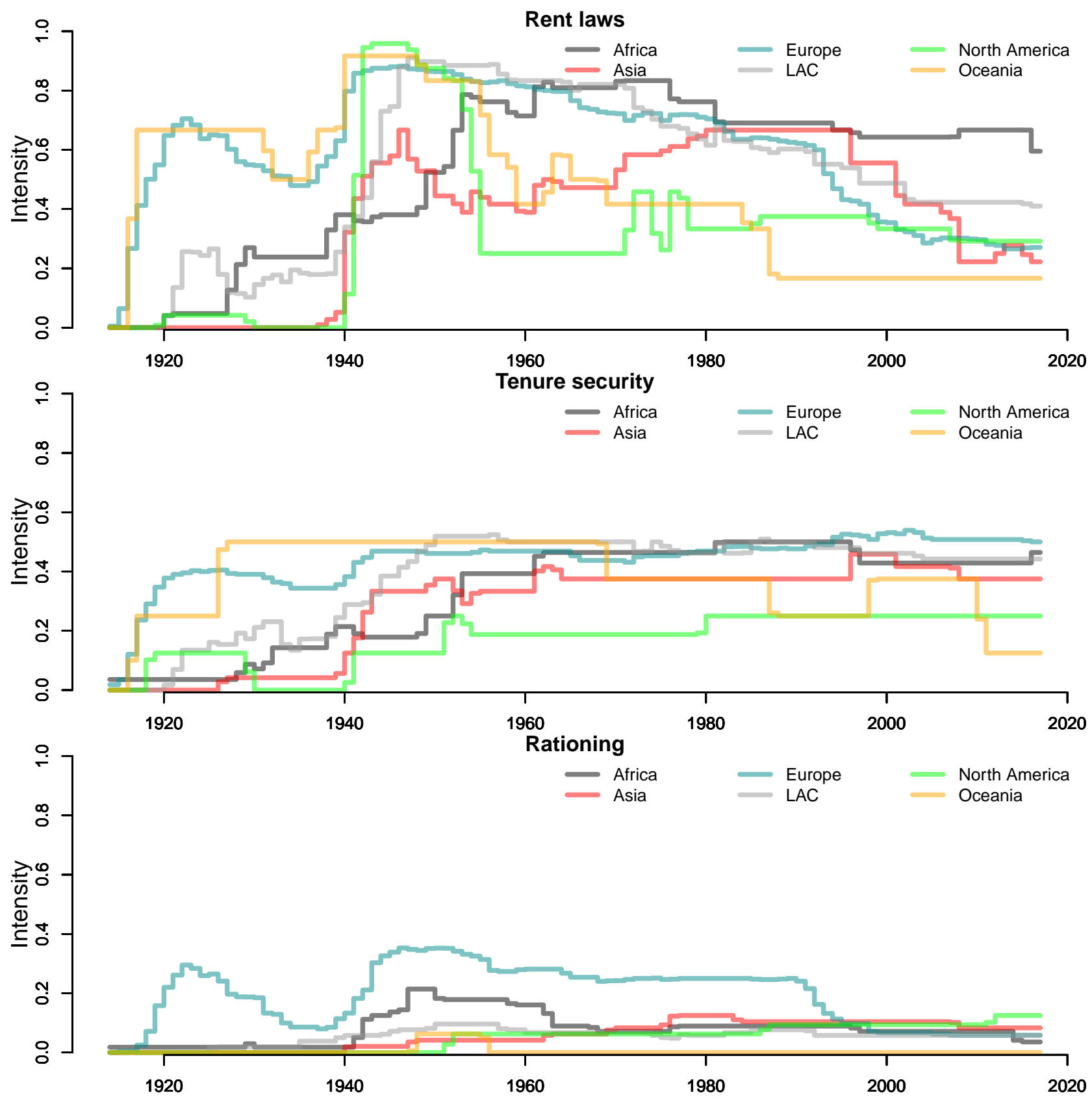


bition of using dwellings for non-residential purposes; see Keating (1983). The continent that most actively took advantage of housing rationing is Europe. The two periods of the most extensive use of such policies coincide with the two world wars and their aftermath. Nevertheless, with the passage of time, European countries, although markedly reducing the application of housing rationing, did not dismantle them completely. In Western Europe, new forms of hous-

ing rationing were sometimes introduced, such as the protection of social composition areas in Germany (Kholodilin, 2017). Latin America and the Caribbean had similar, but somewhat lower, intensities of housing rationing to Europe. Africa and Asia had some episodes (1950s and 2010s) when the intensity of housing rationing exceeded the worldwide average. Oceania only used such policies in the 1950s.

Comparative differences are also noticeable for tenure security, which was rarely cut back once introduced. Here again Anglo-Saxon countries show lower levels of tenant protection than their continental European counterparts. With regard to rent control, Europe was the first to introduce hard controls, but also the first to replace them with softer controls. Again, this trajectory differs from Anglo-Saxon countries, where hard controls were only a war-time emergency measure, after which the free rental market gained the upper hand again. However, continental Europe also differs from the rest of the world, as controls of the first generation began later but with greater intensity and permanence. Only recently did soft controls emerge in these countries. Thus, Europe lies internationally in between the over-regulated Global South (and former socialist countries) and the under-regulated Anglo-Saxon world. There are also notable differences within Europe, as Figure 3 shows. Particularly after the 1970s, countries of German legal origin occupied a middle position in rent regulation, lying between a more under-regulated UK and the more regulated South and North of Europe, focusing more on pronounced rationing regulation.

\section{Estimation results}

\subsection{Estimation technique}

In this section, we estimate the impact of restrictive housing regulations upon homeownership rates (HOR). The availability of longitudinal data suggests the use of a panel data model. Due to multiple missing observations, the data are aggregated at the decade level. 
Figure 3: Rental regulation intensity in Europe by legal origin
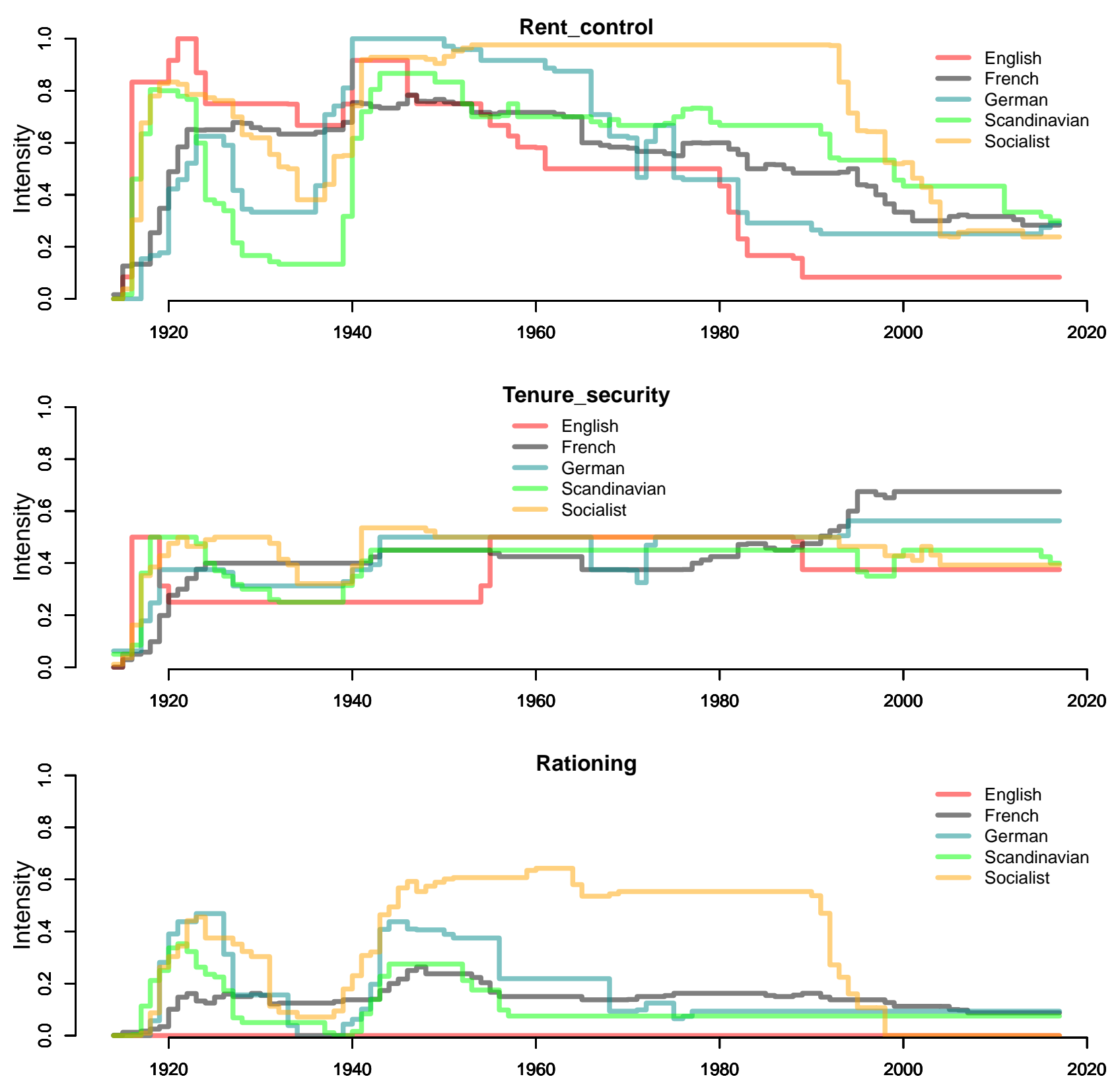
Given the strong persistence of HOR and in order to remove serial correlation and potential non-stationarity, we compute the dependent variable as the first difference of HOR.

$$
y_{i t}=\beta^{\prime} x_{i t}+\eta_{i}+\theta_{t}+v_{i t}
$$

where $y_{i t}$ is the first difference of the HOR in country $i$ in decade $t ; x_{i t}$ is the vector of explanatory variables including the regulation indices; $\eta_{i}$ is the country fixed effects; $\theta_{t}$ is the decade fixed effects; $v_{i t}$ is the random disturbance; and $\beta$ is the vector of coefficients.

Following existing studies on HOR, we include the following control variables: growth rates of real GDP per capita, dependency ratio, nominal long-term interest rates, and new dwelling completions per capita. We use the nominal and not the real interest rates for two reasons. First, as Modigliani and Cohn (1979) and Campbell and Vuolteenaho (2004) show, due to the money illusion, investors seem to value equities using the nominal interest rate instead of the real interest rate. Second, since the computation of real interest rates requires data on the CPI, we would lose observations. Table A4 in Appendix reports sources and presents descriptive statistics for the dependent variable, control variables, and regulation indices.

\subsection{Diagnostic tests}

Before we embark on the estimations, we must conduct some diagnostic tests in order to determine the correct specifications of our models. Table A5 in Appendix contains $p$-values of several specification tests. The first column shows models based on different combinations of regulation indices.

Hausman test. First, we test whether fixed or random effects should be used. The null hypothesis of the corresponding Hausman test is using random effects. In all models, it can be rejected at any conventional significance levels. Thus, we use models with fixed effects.

F-tests for individual and time fixed effects. The second test concerns choosing more specifically the types of fixed effects to use. First, we compare a pooled model with a model containing individual or, in our case, country effects. The null hypothesis of this test is the absence of country effects. It is rejected for all models. The second test compares a model with country effects to a model with both country and time (decade) effects. Again, according to the $H_{0}$, there are no decade effects. It can be rejected at the $1 \%$ significance level in all cases. Therefore, 
we use decade effects.

Durbin-Watson panel test for autocorrelation. The null hypothesis is that all second-order autocovariances for all periods are zero: $\operatorname{cov}\left(\hat{u}_{i t}, \hat{u}_{i, t-2}\right)=0$. It cannot be rejected, as suggested by the high $p$-values close to 1 .

\subsection{Results}

We estimate four different models. They have the same control variables (dependency ratio, condominium dummy, long-term interest rate, and growth of real per-capita GDP), but different combinations of regulation indices. Model 1 includes three aggregate indices (rent laws, tenure security, and housing rationing). Model 2 contains the rental market regulation index (a simple average of rent law and tenure security indices) and housing rationing. Model 3 is similar to model 1, except that the indices of the first- and second-generation rent controls $\left(\mathrm{RC}_{-} 1\right.$ and RC_2) are used instead of the rent laws index. Finally, model 4 differs from model 1 in that it includes the square of the rent control index. The idea is to test for possible non-linear effects: whether very weak or very strong regulations favor ownership, while "balanced" regulation levels encourage tenant occupation.

The estimation results are reported in Table 1 . The model uses an unbalanced panel consisting of 25 countries, ${ }^{3}$ with the number of decades varying between 1 and 13 . As a result, the sample includes 117 observations.

Control variables. The dependency ratio appears to affect the change in HOR positively, since families with children and the elderly are more likely to be homeowners: the former prefer to raise children in green areas, while the latter possess greater wealth, especially in rich countries. By contrast, growth rates of real GDP exert a negative impact on HOR. Increasing GDP is often associated with increasing asset prices, which makes homeownership less affordable. New construction has positive and statistically significant coefficients: an expansion of housing supply opens better opportunities for homeownership. Finally, nominal long-term interest rates are negative and highly significant in all models. The high cost of capital is usually considered a serious obstacle to buying a home.

\footnotetext{
${ }^{3}$ Due to missing observations the effective number of countries is much smaller than the cross-sectional dimension of our regulation data set containing 64 countries.
} 
Table 1: Estimation results of panel data model: basic specification

\begin{tabular}{lcccc}
\hline & Model 1 & Model 2 & Model 3 & Model 4 \\
\hline Rent_laws & $11.91^{* *}$ & & & $30.79^{* * *}$ \\
& $(3.93)$ & & & $(7.16)$ \\
Rent_laws2 & & & & $-19.22^{*}$ \\
& & & & $(7.38)$ \\
RC_1 & & & 4.11 & \\
& & & $(2.07)$ & \\
RC_2 & & & 1.38 & \\
& & & $(2.48)$ & \\
Tenure_security & -0.28 & & -1.67 & -1.97 \\
& $(2.72)$ & & $(4.44)$ & $(3.37)$ \\
Rationing & 20.68 & $24.35^{*}$ & 17.87 & 17.57 \\
& $(10.93)$ & $(9.92)$ & $(12.39)$ & $(11.10)$ \\
RMRI & & $11.02^{*}$ & & \\
& & $(4.76)$ & & \\
Dep_ratio & $33.98^{*}$ & 32.29 & 23.20 & 29.51 \\
& $(16.33)$ & $(16.36)$ & $(22.17)$ & $(14.93)$ \\
DLGDP_PC & $-16.57^{*}$ & -12.42 & $-14.91^{*}$ & $-14.45^{*}$ \\
& $(6.59)$ & $(6.81)$ & $(6.83)$ & $(6.65)$ \\
Condo & 0.93 & 1.11 & 0.29 & 0.39 \\
& $(3.54)$ & $(3.00)$ & $(3.56)$ & $(3.48)$ \\
LNew_const & $4.06^{*}$ & 3.14 & 2.53 & $3.62^{*}$ \\
& $(1.93)$ & $(1.83)$ & $(1.86)$ & $(1.79)$ \\
LTIR & $-0.64^{* * *}$ & $-0.61^{* * *}$ & $-0.60^{* * *}$ & $-0.61^{* * *}$ \\
& $(0.10)$ & $(0.10)$ & $(0.10)$ & $(0.10)$ \\
\hline $\mathrm{R}^{2}$ & 0.37 & 0.32 & 0.33 & 0.40 \\
Adj. R ${ }^{2}$ & 0.02 & -0.05 & -0.07 & 0.04 \\
Num. obs. & 117 & 117 & 117 & 117 \\
\hline
\end{tabular}


Regulation indices. The rent laws variable has a positive and statistically significant effect. A one unit increase in the stringency of rent control leads to a 12 percentage point increase in the change of HOR. As expected, stricter rent control causes an erosion of the real value of the rental revenues and, thus, reduces the private rental housing stock. Interestingly, the rent control appears to exert a non-linear impact on HOR, as the results of Model 4 show. Up to a rent regulation stringency of 0.65 , which corresponds to first-generation rent control, HOR formation accelerates, after that point HOR grows at a slower pace. Housing rationing is also positive, but significant only in Model 2. However, the magnitude of its effects is double of that of rent control. By restricting the ability of landlords to control their properties, the state diminishes their incentives to hold rental dwellings. The coefficients for tenure security and RMRI are not significant.

\section{Discussion and conclusion}

Homeownership rates have increased in virtually all countries since the 1920s. While urbanizing and industrializing European countries were still homeownership laggards in the early 20th century, they have broadly caught up with Anglo-Saxon countries, but still lie below the HOR found in the Global South. Our findings suggest that these general trends were brought about not so much by economic or demographic background variables or direct subsidy programs, but rather indirectly by the use of tenancy regulation as a form of social policy.

As with many other welfare policies, tenancy regulation was pushed by particular war-time solidarity with families of urban soldiers and tenants facing high rent inflation. With European countries and, in particular, cities dominated by tenant majorities, largely outnumbering the dispersed private landlord class, it is not surprising that tenancy regulation was maintained even after the wars in Europe concluded. Strong tenant movements emerged, naturally outnumbering landlords and property-owner organizations. It was not just left-wing parties that made the protection of tenants a policy issue, but conservative governments also enacted protective legislation in the post-war era. In this regard, private tenancy politics has much in common with housing and other welfare policy fields. From a comparative perspective, the already high HOR in Anglo-Saxon countries and the low initial urbanization in the Global South probably explain the lag or absence of this regulation outside of Europe. 
As effective as these measures were in the social protection of rental housing market insiders, they have effectively crowded out private tenancy by homeownership. By protecting tenants in the short-term, regulation contributed to their long-term disappearance. The most intrusive rationing measures, along with the protection of tenants and rent control, significantly increased HOR in the long run, partially explaining why homeownership rates increased, why Europe caught up with Anglo-Saxon countries, and why the Global South still has some of the highest

HOR. They might also explain why some of the largest homeownership spurts in countries occurred around the war decades; see Fetter (2016). Finally, they might also explain some of the intra-European homeownership differences: Southern European countries, like Spain, Portugal, Italy, and France, used hard rent controls more than other countries, largely replacing private tenancy with condominium ownership. This occurred, even intentionally, in an effort to transform tenant societies into homeownership societies; it was not just as a by-product of excessive goodwill toward tenants (Di Feliciantonio and Aalbers, 2018).

The effect of tenant protection on homeownership has not been globally positive. The non-linear association suggests that rent control has a positive, but marginally declining, effect. Moreover, century-old rent legislation has not completely destroyed rental markets. Particularly in German-speaking countries, rent regulation has long coexisted with tenancy rates exceeding 50 percent, if not larger. Finally, this research is only able to measure the absence or presence of regulation of different sorts. Further fine-grained analyses should investigate how much specific regulation results in crowding out.

\section{Literature}

Andrews, D., A. Caldera Sánchez, and Å. Johansson (2011). Housing markets and structural policies in OECD countries. OECD Economic Department Working Papers (836).

Arnott, R. (1995). Time for revisionism on rent control? Journal of Economic Perspectives 9(1), 99-120.

Blanco Blanco, A. G. (2014). La realidad del alquiler en América Latina y el Caribe. In A. G. Blanco, V. Fretes Cibils, and A. F. Muñoz (Eds.), Busco casa en arriendo. Promover el alquiler tiene sentido. New York: Banco Interamericano de Desarrollo. 
Borjas, G. J. (2002). Homeownership in the immigrant population. Journal of urban economics 52(3), 448-476.

Botero, J., S. Djankov, R. LaPorta, F. L. de Silanes, and A. Shleifer (2004). The regulation of labor. Quarterly Journal of Economics 119(4), 1339-1382.

Burgess, S. L. (1982). Determinants of homeownership: A comparison of single female and single male headed households. Housing and Society 9(2), 87-94.

Campbell, J. Y. and T. Vuolteenaho (2004). Bad beta, good beta. American Economic Review $94(5), 1249-1275$.

Chevan, A. (1989). The growth of home ownership: 1940-1980. Demography 26(2), 249-266.

Deakin, S., P. Lele, and M. Siems (2007). The evolution of labour law: Calibrating and comparing regulatory regimes. Working papers, Centre for Business Research, University of Cambridge.

Di Feliciantonio, C. and M. B. Aalbers (2018). The prehistories of neoliberal housing policies in Italy and Spain and their reification in times of crisis. Housing Policy Debate 28(1), 135-151.

Djankov, S., R. La Porta, F. López de Silanes, and A. Shleifer (2003). Courts: The Lex Mundi project. The Quarterly Journal of Economics 118(2), 453-517.

Early, D. W. and E. O. Olsen (1998). Rent control and homelessness. Regional Science and Urban Economics 28(6), 797-816.

Fetter, D. K. (2016). The home front: Rent control and the rapid wartime increase in home ownership. The Journal of Economic History 76(4), 1001-1043.

Field, E., M. Levinson, R. Pande, and S. Visaria (2008). Segregation, rent control, and riots: The economics of religious conflict in an Indian city. The American Economic Review $98(2)$, $505-510$.

Fisher, L. M. and A. J. Jaffe (2003). Determinants of international home ownership rates. Housing finance international 18(1), 34-42. 
Führer, K. C. (1995). Managing scarcity: The german housing shortage and the controlled economy. German History 13(3), 326.

Glaeser, E. L. (2003). Does rent control reduce segregation? Swedish Economic Policy Review 10, 179-202.

Grimes, P. W. and G. A. Chressanthis (1997). Assessing the effect of rent control on homelessness. Journal of Urban Economics 41(1), 23-37.

Gwin, C. R. and S.-E. Ong (2008). Do we really understand homeownership rates? An international study. International Journal of Housing Markets and Analysis 1(1), 52-67.

International Labour Office (1924). European housing problems since the war. Imprimeries réunies S.A.: Geneva.

Iwata, S. (2002). The Japanese tenant protection law and asymmetric information on tenure length. Journal of Housing Economics 11 (2), 125-151.

Keating, W. D. (1983). Rent control in California: Responding to the rental housing crisis. Institute of Governmental Studies, University of California, Berkeley.

Kholodilin, K. A. (2017). Quantifying a century of state intervention in rental housing in Germany. Urban Research and Practice 10(3), 267-328.

Kholodilin, K. A. (2018). Measuring stick-style housing policies: A multi-country longitudinal database of governmental regulations. DIW Berlin Discussion Paper 1727.

Kohl, S. (2017). Homeownership, Renting and Society: Historical and Comparative Perspectives. London: Routledge.

Kohl, S. (2018a). The political economy of homeownership: A comparative analysis of homeownership ideology through party manifestos. Socio-Economic Review.

Kohl, S. (2018b). Too much mortgage debt? the effect of financialization on new construction and residential capital investment. Unpublished Manuscript. 
Krol, R. and S. Svorny (2005). The effect of rent control on commute times. Journal of Urban Economics 58(3), 421-436.

Kutty, N. K. (1996). The impact of rent control on housing maintenance: A dynamic analysis incorporating European and North American rent regulations. Housing Studies 11(1), 69-88.

LaPorta, R., F. L. de Silanes, A. Shleifer, and R. W. Vishny (1998). Law and finance. Journal of Political Economy 106(6), 1113-1155.

Lauridsen, J., N. Nannerup, and M. Skak (2009). Geographic and dynamic heterogeneity of home ownership. Journal of Housing and the Built Environment 24(1), 1-17.

Malpezzi, S. and G. Ball (1993). Measuring the urban policy environment: an exploratory analysis using rent controls. Habitat International 17(2), 39-52.

Miletić, A. R. (2016). Tenancy vs. ownership rights. housing rent control in Southeast and East-Central Europe, 1918-1928. Mesto a dejiny 5(1), 51-74.

Modigliani, F. and R. A. Cohn (1979). Inflation, rational valuation and the market. Financial Analysts Journal, 24-44.

Munch, J. R. and M. Svarer (2002). Rent control and tenancy duration. Journal of Urban Economics 52(3), 542-560.

Schmidt, S. (1989). Convergence theory, labour movements, and corporatism: The case of housing 1. Scandinavian Housing and Planning Research 6(2), 83-101.

Tan, T.-H. (2008). Determinants of homeownership in Malaysia. Habitat International 32(3), $318-335$.

Weber, J. P. (2017). The regulation of private tenancies - a multi-country analysis. Dissertation. 


\section{Appendix}

Table A1: List of countries, for which regulation indices are constructed

\begin{tabular}{l|l|l|l}
\hline Continent & Countries & $\begin{array}{l}\text { Sample } \\
\text { size }\end{array}$ & $\begin{array}{l}\text { Total } \\
\text { coun- } \\
\text { tries } \\
\text { (states) }\end{array}$ \\
\hline Africa & Angola, Madagascar, Mali, Morocco, Niger, Togo, Tunisia & 7 & 60 \\
\hline Asia & Cyprus, Macao, Philippines, Singapore & 4 & 51 \\
\hline Europe & $\begin{array}{l}\text { Andorra, Austria, Belgium, Czech Republic, Denmark, Es- } \\
\text { tonia, Finland, France, Germany, Greece, Iceland, Ireland, }\end{array}$ & 28 & 53 \\
\hline $\begin{array}{l}\text { Latin Amer- } \\
\text { ica }\end{array}$ & $\begin{array}{l}\text { Argentina, Liechtenstein, Lithuania, Luxembourg, Monaco, Nor- } \\
\text { Caribbean }\end{array}$ & $\begin{array}{l}\text { ico (Distrito Federal), Nicaragua, Panama, Peru, Salvador, } \\
\text { vakinidad and Tobago, Uruguay }\end{array}$ & \\
\hline North Amer- \\
ica
\end{tabular}




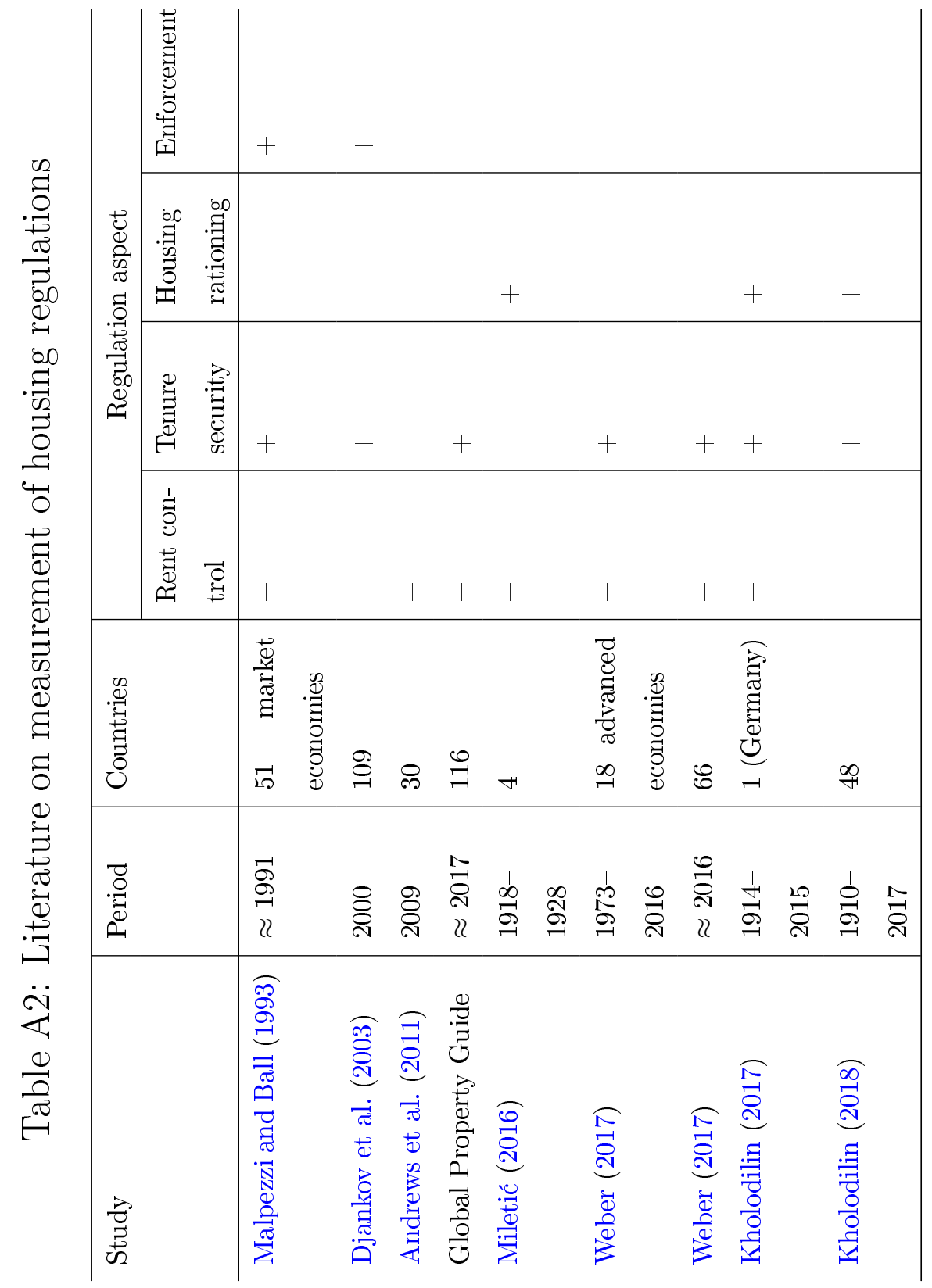


Table A3: Literature on HOR determinants

\begin{tabular}{|c|c|c|c|c|c|c|c|}
\hline $\begin{array}{l}\text { Study design and explanatory vari- } \\
\text { ables }\end{array}$ & $\begin{array}{l}\text { Lauridsen } \\
\text { et al. } \\
(2009)\end{array}$ & $\begin{array}{l}\text { Chevan } \\
(1989)\end{array}$ & $\begin{array}{l}\text { Fisher } \\
\text { and Jaffe } \\
(2003)\end{array}$ & $\begin{array}{l}\text { Schmidt } \\
(1989)\end{array}$ & $\begin{array}{l}\text { Gwin and } \\
\text { Ong (2008) }\end{array}$ & $\begin{array}{l}\text { Andrews } \\
\text { et al. } \\
(2011)\end{array}$ & $\begin{array}{l}\text { Blanco } \\
\text { Blanco } \\
(2014)\end{array}$ \\
\hline Countries/regions & $\begin{array}{l}270 \text { Danish } \\
\text { municipali- } \\
\text { ties }\end{array}$ & $\begin{array}{l}\text { HOR in the } \\
\text { USA }\end{array}$ & $\begin{array}{l}106 \text { coun- } \\
\text { tries }\end{array}$ & $\begin{array}{l}18 \quad \text { coun- } \\
\text { tries }\end{array}$ & $\begin{array}{l}232-237 \\
\text { cities from } \\
111-113 \\
\text { countries }\end{array}$ & $\begin{array}{l}\text { households } \\
\text { in } 23 \\
\text { countries }\end{array}$ & \\
\hline Period & $1999-2004$ & 1930-1979 & $\begin{array}{l}\text { between } \\
1980 \text { and } \\
1999\end{array}$ & $\begin{array}{l}\text { early } \\
\text { 1970s- } \\
\text { mid-1980s }\end{array}$ & $\begin{array}{l}1993 \text { and } \\
1998\end{array}$ & 2009 & 2006-2011 \\
\hline $\begin{array}{l}\text { Method } \\
\text { Data }\end{array}$ & & logit & $\begin{array}{l}\text { OLS } \\
\text { cross- } \\
\text { section }\end{array}$ & & & probit & $\begin{array}{l}\text { OLS } \\
\text { cross- } \\
\text { section }\end{array}$ \\
\hline Rent regulations & + & & & & & & \\
\hline $\begin{array}{l}\text { Government encouragement of } \\
\text { home ownership }\end{array}$ & & 0 & & & & & \\
\hline $\begin{array}{l}\text { Share of population living in sub- } \\
\text { sidized housing }\end{array}$ & + & & & & & & \\
\hline $\begin{array}{l}\text { Share of households receiving } \\
\text { housing subsidies }\end{array}$ & + & & & & & & \\
\hline $\begin{array}{l}\text { Share of } 15-66 \text { year-olds receiving } \\
\text { rent subsidies }\end{array}$ & + & & & & & & \\
\hline Share of govt expenditure in GDP & & & & - & & & \\
\hline Housing price or construction cost & + & + & & & & & \\
\hline Price-to-rent ratio & & 0 & & & + & & \\
\hline Property tax & + & & & & & & \\
\hline Tax rate & - & & & & & & \\
\hline Tax base & - & & & & & & \\
\hline Tax advantage of homeowners & & 0 & & & & + & \\
\hline Mandatory finance & & & + & & & & \\
\hline Financial reform index & & & & & & + & \\
\hline Interest rate & & & & & + & & \\
\hline Loan-to-value ratio & & & & & & + & \\
\hline Population density & + & & & & & & \\
\hline Urbanization & + & & + & & & & \\
\hline Share of young population & - & & - & & & & \\
\hline Share of working age population & + & & + & & & & \\
\hline Share of old population & + & & & & & & \\
\hline Share of population widowed & - & & & & & & \\
\hline Share of population divorced & + & & & & & & \\
\hline Share of population unmarried & + & & & & & & \\
\hline $\begin{array}{l}\text { Share of households with children } \\
>18\end{array}$ & + & & & & & & \\
\hline
\end{tabular}




\section{Table A3: Literature on HOR determinants}

\begin{tabular}{|c|c|c|c|c|c|c|c|}
\hline $\begin{array}{l}\text { Study design and explanatory vari- } \\
\text { ables }\end{array}$ & $\begin{array}{l}\text { Lauridsen } \\
\text { et al. } \\
(2009)\end{array}$ & $\begin{array}{l}\text { Chevan } \\
(1989)\end{array}$ & $\begin{array}{l}\text { Fisher } \\
\text { and Jaffe } \\
(2003)\end{array}$ & $\begin{array}{l}\text { Schmidt } \\
(1989)\end{array}$ & $\begin{array}{l}\text { Gwin and } \\
\text { Ong (2008) }\end{array}$ & $\begin{array}{l}\text { Andrews } \\
\text { et al. } \\
(2011)\end{array}$ & $\begin{array}{l}\text { Blanco } \\
\text { Blanco } \\
(2014)\end{array}$ \\
\hline Share of households without chil- & - & & & & & & \\
\hline $\begin{array}{l}\text { dren }<18 \\
\text { Share of population with higher ed- } \\
\text { ucation }\end{array}$ & - & & & & & & \\
\hline $\begin{array}{l}\text { Share of population on social dis- } \\
\text { ability pension }\end{array}$ & - & & & & & & \\
\hline $\begin{array}{l}\text { Share of population receiving so- } \\
\text { cial benefits }\end{array}$ & + & & & & & & \\
\hline Unemployment rate & - & & & & & & \\
\hline $\begin{array}{l}\text { Number of immigrants from the } \\
\text { 3rd world }\end{array}$ & + & & & & & & \\
\hline GDP per capita or GDP growth & & & + & & + & & \\
\hline Share of socialists in parliament & & & & 0 & & & \\
\hline Continent dummy & & & & & - & & \\
\hline Communist country & & & & & - & & \\
\hline
\end{tabular}




\section{Table A4: Description of variables used in the analysis}

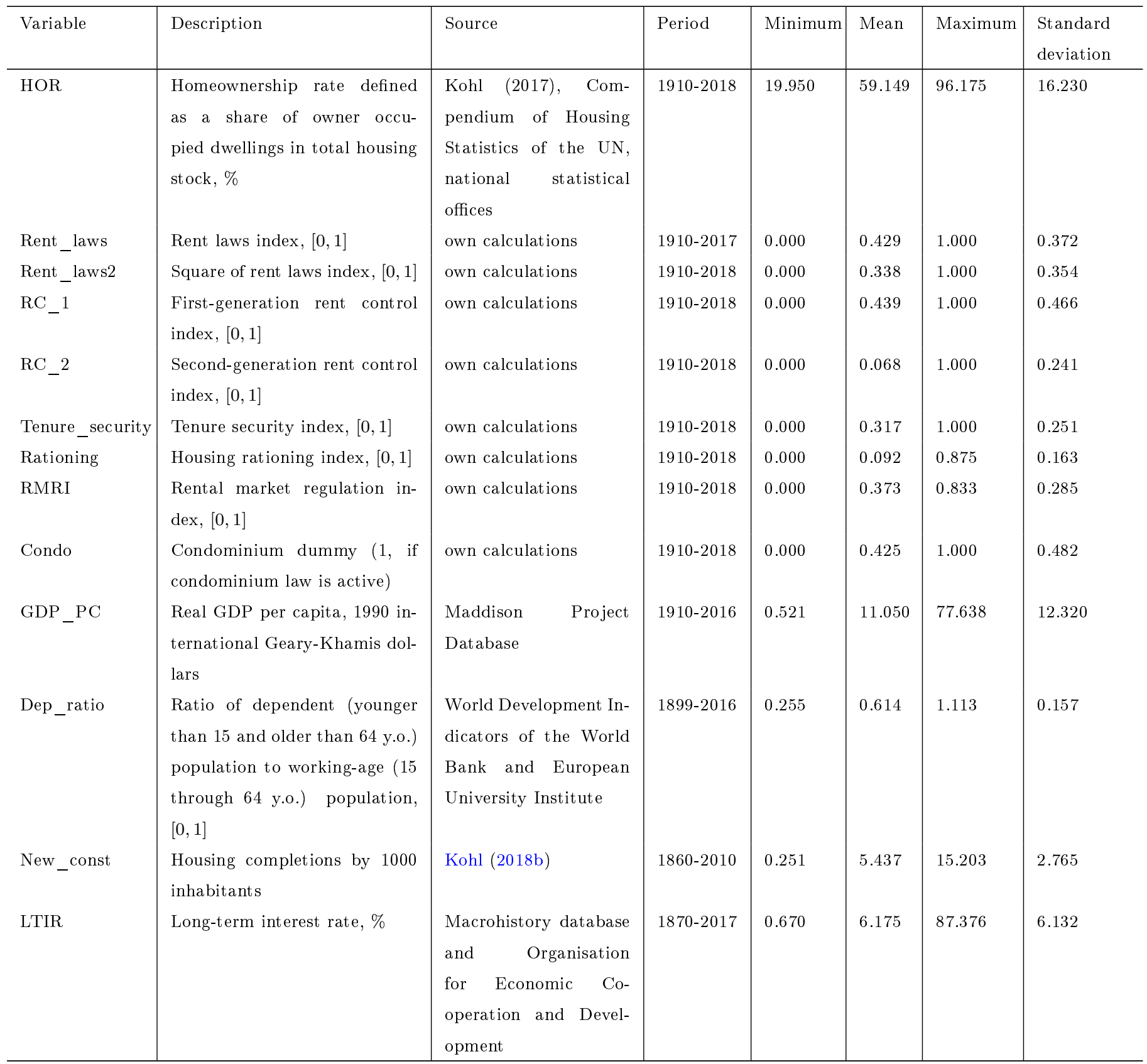




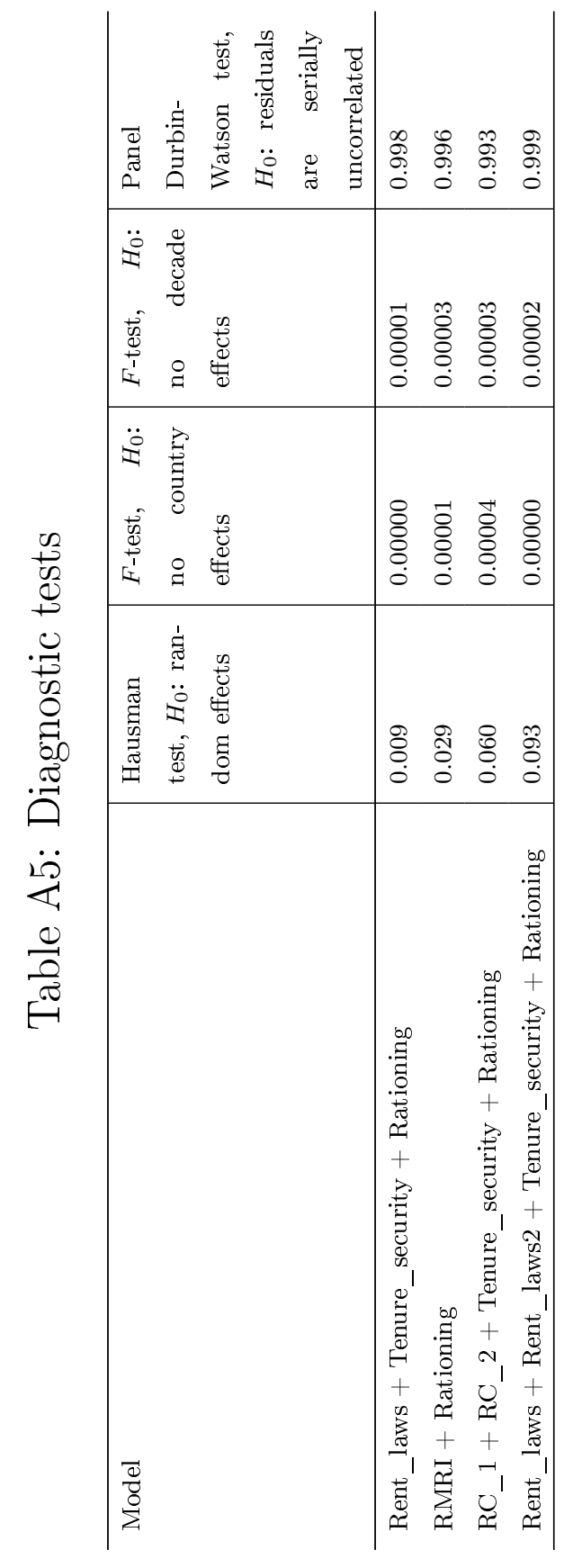

